\title{
A new approach to silicon rhodamines by Suzuki-Miyaura coupling - scope and limitations
}

\author{
Thines Kanagasundaram ${ }^{1,2}$, Antje Timmermann ${ }^{1,2}$, Carsten S. Kramer ${ }^{*}, \S$ \\ and Klaus Kopka ${ }^{1,3, \S}$
}

\section{Full Research Paper}

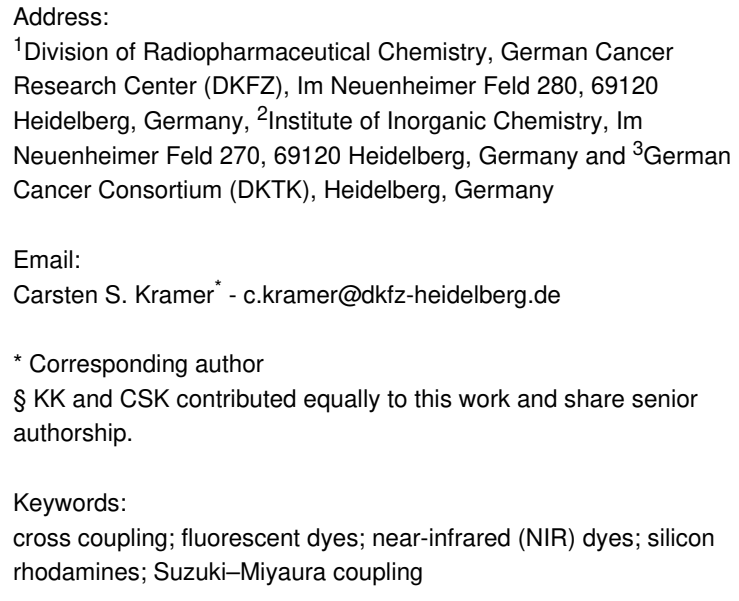

${ }^{1}$ Division of Radiopharmaceutical Chemistry, German Cancer Research Center (DKFZ), Im Neuenheimer Feld 280, 69120 Heidelberg, Germany, ${ }^{2}$ Institute of Inorganic Chemistry, Im Neuenheimer Feld 270, 69120 Heidelberg, Germany and ${ }^{3}$ German Cancer Consortium (DKTK), Heidelberg, Germany

Email:

Carsten S. Kramer ${ }^{*}$ - c.kramer@dkfz-heidelberg.de

* Corresponding author

$\S \mathrm{KK}$ and CSK contributed equally to this work and share senior authorship.

Keywords:

cross coupling; fluorescent dyes; near-infrared (NIR) dyes; silicon rhodamines; Suzuki-Miyaura coupling

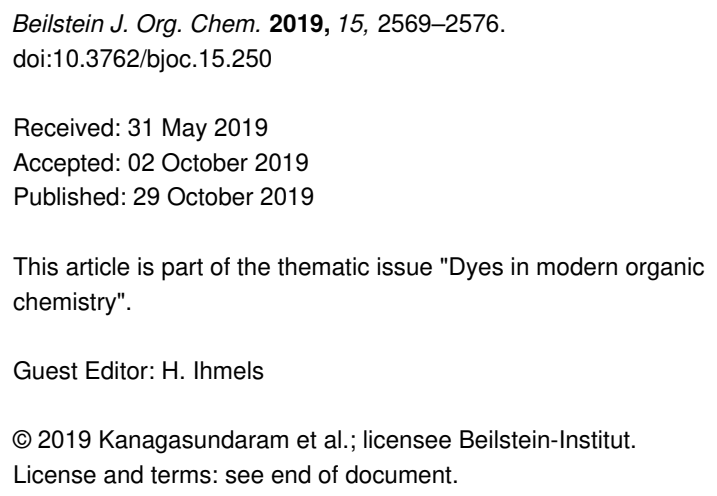

\begin{abstract}
Background: Silicon rhodamines are of particular interest because of their advantageous dye properties (fluorescence- and biostability, quantum efficiency, tolerance to photobleaching). Therefore, silicon rhodamines find frequent application in STED (stimulated emission depletion) microscopy, as sensor molecules for, e.g., ions and as fluorophores for the optical imaging of tumors. Different strategies were already employed for their synthesis. Because of just three known literature examples in which Suzuki-Miyaura cross couplings gave access to silicon rhodamines in poor to moderate yields, we wanted to improve these first valuable experimental results.
\end{abstract}

Results: The preparation of the xanthene triflate was enhanced and several boron sources were screened to find the optimal coupling partner. After optimization of the palladium catalyst, different substituted boroxines were assessed to explore the scope of the Pd-catalyzed cross-coupling reaction.

Conclusions: A number of silicon rhodamines were synthesized under the optimized conditions in up to $91 \%$ yield without the necessity of HPLC purification. Moreover, silicon rhodamines functionalized with free acid moieties are directly accessible in contrast to previously described methods. 


\section{Introduction}

Silicon rhodamines are versatile fluorescent dyes that found extensive use in super-resolution microscopy [1-8] and as probes for targeting various biomolecules [9-12] or sensors for metal ions [13-17], $\mathrm{pH}$ [15], voltage [18] or metabolites [19-22] Since our group is interested in synthesizing new tumor tracers for intraoperative imaging of cancerous lesions, we were interested in silicon rhodamines due to their fluorescence properties in the biological window (650 nm to $1350 \mathrm{~nm}$ ). While clinically approved fluorescence dyes like ICG (indocyanine green, $M_{\mathrm{w}}=775 \mathrm{~g} / \mathrm{mol}$ ) have a high molecular weight and could therefore alter pharmacokinetic or -dynamic properties of the tumor tracers, silicon rhodamines are relatively small and already examined as fluorophores for the optical imaging of tumors. Using silicon rhodamine SiR700 a more enhanced tumor-tobackground ratio in optical imaging could be achieved compared to the cyanine based dyes Cy5.5 and Alexa Fluor ${ }^{\circledR} 680$ [23]. Moreover, silicon rhodamines demonstrated in in vivo imaging experiments excellent fluorescence properties and biostabilities [23] as well as exhibited high quantum efficiencies with high tolerance to photobleaching [24]. A silicon rhodamine antibody conjugate could also be successfully applied for optical imaging of a xenograft tumor (human malignant meningioma) in a mouse model [24]. Again, in direct comparison with the cyanine dye Cy5.5, the silicon rhodamine conjugate showed no fading indicating that silicon rhodamine dyes are more suitable for long time observation than cyaninebased fluorophores [24].

Different synthetic approaches were established to form the silicon rhodamine framework 1 (Scheme 1). While the group of Wu used a copper(II) bromide-catalyzed solvent-free condensation of a diarylsilane 2 with various benzaldehydes 3 [25], Sparr and Fischer added the double Grignard reagent 4 to methyl esters 5 [26]. A similar approach was established by Lavis, herein electrophiles (anhydrides or esters) were added to lithium or magnesium organyls 4 [27]. Johnsson and co-workers<smiles>O=Cc1[R]ccc1</smiles><smiles>[R]N([R1])c1cccc([Si](C)(C)c2cccc(N([R])[R])c2)c1</smiles>

2 Wu et al. [25]

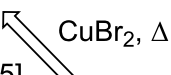<smiles></smiles>

1<smiles>COC(=O)c1ccccc1</smiles><smiles>[M]c1ccc(N([R])[R1])cc1[Si](C)(C)C1=CCC([M])C(N([R])[R])=C1</smiles>

$$
4
$$

$M=L i, M g$

Sparr et al. [26]

Lavis et al. [27]<smiles>[R]N([R1])c1ccc2c(c1)[Si](C)(C)c1cc(N([R])[R])ccc1C2=O</smiles>

6
1.) $-78^{\circ} \mathrm{C}$ to rt, $\mathrm{THF}$

2.) chloranil, DCM

Johnsson et al. [8]

Nagano et al. [14]<smiles>[Tl]c1ccccc1</smiles><smiles></smiles> 
could establish dye formation by addition of aryllithium $\mathbf{7}$ to the silicon xanthone 6 [8]. A related strategy, adding lithium compound $\mathbf{7}$ to a preformed tricyclic system $\mathbf{8}$, was used by Nagano et al. to synthesize the $\mathrm{Ge}$ and $\mathrm{Sn}$ rhodamine analogues [14].

In a recent publication, Urano et al. synthesized the rhodamines 13-15 by coupling the triflate of xanthone 12 with boroxines 9b-11b (Scheme 2) [22,28]. Hereby, the boroxines 9b-11b were accessible by thermal dehydration of the corresponding boronic acids $9 \mathbf{a}-\mathbf{1 1 a}$. With this procedure product $\mathbf{1 3}$ was obtained in only $6 \%$ yield, which is presumably due to a competing coupling reaction of the boroxine moiety of $9 \mathbf{b}$ with the chlorine atom of $\mathbf{9 b}$ or sterical reasons (the chlorine in 2 '-position might lead to repulsion during the cross-coupling reaction). The reaction of the triflate with cyano-substituted phenylboroxines $\mathbf{1 0 b}$ and $\mathbf{1 1 b}$ led to silicon rhodamine dyes 14 and $\mathbf{1 5}$ in poor yields of 23 and $19 \%$, respectively. The reaction conditions applied for the cross coupling of the triflate were similar to those published by Calitree and Detty for the coupling of the triflates derived from the $\mathrm{O}, \mathrm{S}, \mathrm{Se}$, and Te-xanthones 16 with various phenylboroxines (bearing nitro, carboxylic acid, methyl and methoxy substituents) [29]. Here yields of 53-79\% were obtained (for $\mathrm{O}$ and $\mathrm{S}$ analogues; 85-99\% yields based on recovered starting material (brsm)). Since the yields reported by Urano for the Si-analogous Suzuki reactions were much lower (6-23\%) [22], we wanted to examine if the aforementioned substrates were outliers and a crosscoupling reaction could be a valuable approach to silicon<smiles>[R]c1ccc(B2OB(c3ccc([R])c([R])c3[R])C(B(O)c3ccccc3C)B(c3ccc([R])c([R])c3[R])O2)c([R])c1[R]</smiles>

9a $R^{1}=C l, R^{2}=H, \quad R^{3}=H$
10a $R^{1}=H, R^{2}=C N, R^{3}=H$
11a $R^{1}=H, R^{2}=H, \quad R^{3}=C N$

1.) 1.2 equiv $\mathrm{Tf}_{2} \mathrm{O}, \mathrm{MeCN}, \mathrm{rt}$

1.6 equiv boroxine

6 equiv $\mathrm{Na}_{2} \mathrm{CO}_{3}$

$70{ }^{\circ} \mathrm{C}, \mathrm{MeCN}$

3.) $\mathrm{H}_{2} \mathrm{O}$, then HPLC<smiles>CN(C)c1ccc2c(c1)[Si](C)(C)c1cc(N(C)C)ccc1C2=O</smiles>

12<smiles>[X]c1cc(N(C)C)ccc1C(=O)c1ccc(N(C)C)cc1[X]</smiles>

16
2.) $20 \mathrm{~mol} \% \mathrm{PdCl}_{2}\left(\mathrm{PPh}_{3}\right)_{2}$

9b $\mathrm{R}^{1}=\mathrm{Cl}, \mathrm{R}^{2}=\mathrm{H}, \quad \mathrm{R}^{3}=\mathrm{H}$

10b $R^{1}=H, R^{2}=C N, R^{3}=H$

11b $R^{1}=H, R^{2}=H, \quad R^{3}=C N$<smiles>[R]c1ccc(C2=C3C=CC(=[N+](C)C)C=C3[Si](C)(C)c3cc(N(C)C)ccc32)c([R])c1[R]</smiles>

$$
\begin{aligned}
& 13 R^{1}=\mathrm{Cl}, \mathrm{R}^{2}=H, \quad \mathrm{R}^{3}=H \quad(6 \%) \\
& 14 \mathrm{R}^{1}=\mathrm{H}, \mathrm{R}^{2}=\mathrm{CN}, \mathrm{R}^{3}=\mathrm{H} \quad(23 \%) \\
& 15 \mathrm{R}^{1}=\mathrm{H}, \mathrm{R}^{2}=H, \quad \mathrm{R}^{3}=\mathrm{CN}(19 \%)
\end{aligned}
$$

1.) 1.1 equiv $\mathrm{Tf}_{2} \mathrm{O}, \mathrm{MeCN}$, rt

2.) $10 \mathrm{~mol} \% \mathrm{PdCl}_{2}\left(\mathrm{PPh}_{3}\right)_{2}$

1 equiv boroxine

3 equiv $\mathrm{Na}_{2} \mathrm{CO}_{3}$

$55^{\circ} \mathrm{C}, \mathrm{MeCN}$

then work-up

3.) $\mathrm{HY}, \mathrm{H}_{2} \mathrm{O}$

$\mathrm{X}=\mathrm{O}, \mathrm{S}, \mathrm{Se}, \mathrm{Te}$

$\mathrm{Y}=\mathrm{PF}_{6}, \mathrm{Cl}$

$\mathrm{R}=\mathrm{H}, \mathrm{Me}, \mathrm{OMe}, \mathrm{COOH}, \mathrm{NO}_{2}$<smiles></smiles>

17

Scheme 2: Previous work from Calitree [29] and Urano [22,28] on the Suzuki-Miyaura coupling of triflates, derived from xanthones 12 and 16, with boroxines. 
rhodamines. Thus, we aimed at the optimization of coupling conditions as well as evaluation of the best boron compounds for coupling. Since carboxylic acid-substituted dyes like compound $17(\mathrm{X}=\mathrm{Si}, \mathrm{R}=\mathrm{COOH})$ can be easily coupled to tumor binding vectors, we wanted to investigate if these dyes are also accessible by Suzuki-Miyaura coupling.

\section{Results and Discussion Optimization of reaction conditions}

At first we investigated the effects of different catalysts and boron compounds on the synthesis of silicon rhodamine $\mathbf{2 2}$ via
Suzuki-Miyaura cross coupling (Scheme 3, Table 1). Triflate 21 was obtained without further purification from $\mathbf{1 2}$ by addition of triflic anhydride in dry acetonitrile. Boroxine $\mathbf{1 8 b}$ was formed by heating of boronic acid (18a) at $110{ }^{\circ} \mathrm{C}$ because it was shown by Calitree and Detty that free boronic acid leads to the destruction of the triflate, resulting in the corresponding xanthone [29]. Applying standard conditions on xanthone 12 by treatment with triflic anhydride in dry acetonitrile and subsequent addition of base, catalyst and boroxine $\mathbf{1 8 b}$ yielded the desired fluorophore $\mathbf{2 2}$ in $41 \%$ yield together with unreacted xanthone 12 (Table 1, entry 1). Since the initial triflate forma-

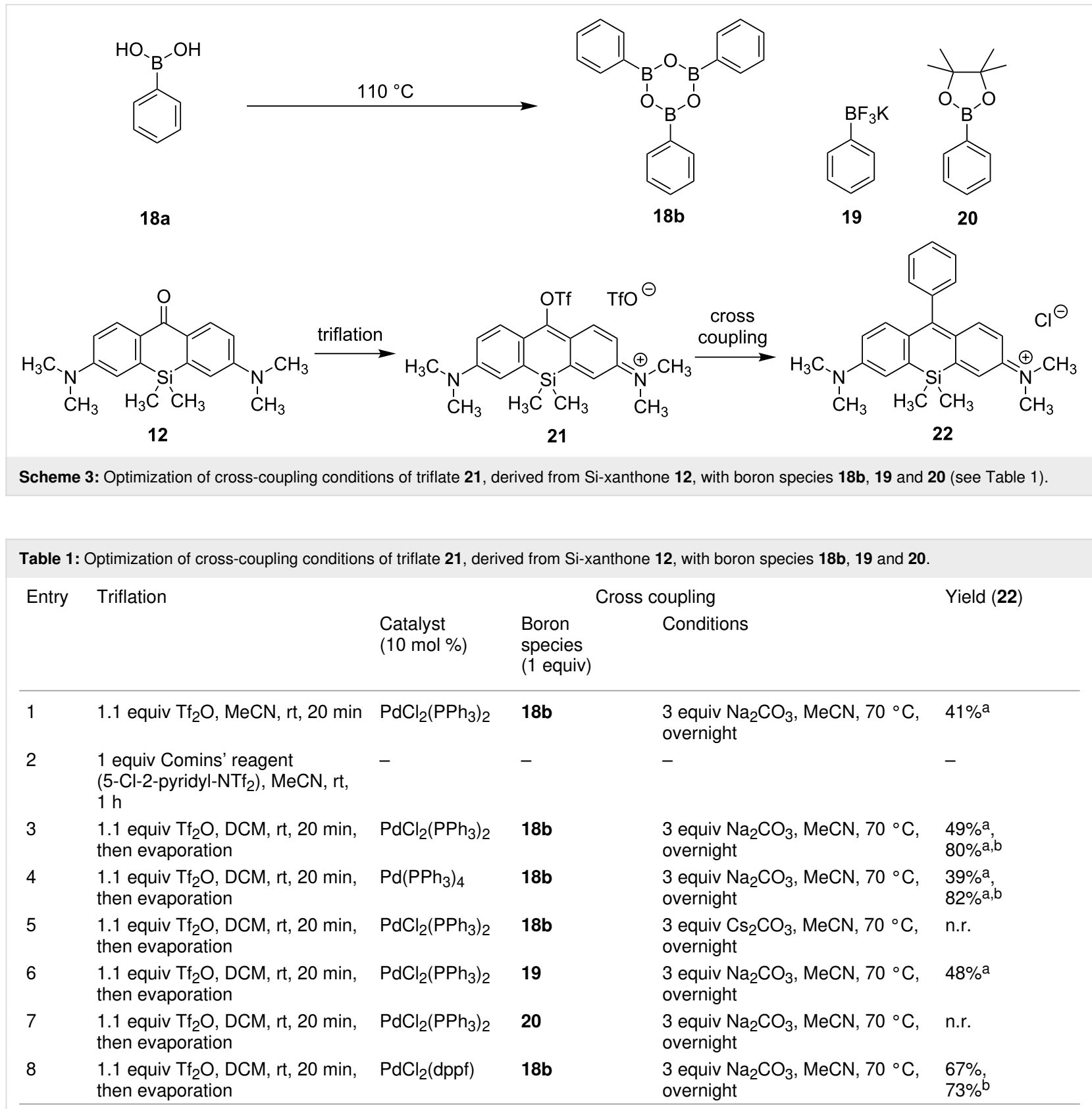

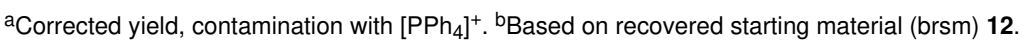


tion to 21 was unreliable and often incomplete, leading to lower yields, Comins reagent was investigated as an alternative triflation reagent. Notably, the use of Comins reagent showed no transformation from the yellow xanthone 12 to the deep blue triflate 21 at all (Table 1, entry 2). Exchange of anhydrous acetonitrile by anhydrous dichloromethane, which was removed in vacuo prior to coupling, provided triflate $\mathbf{2 1}$ as a blue salt without xanthone residues, hereby the yield could be slightly enhanced but still the conditions of the coupling reaction led to some back reaction of $\mathbf{2 1}$ to $\mathbf{1 2}$ (Table 1, entry 3). While the use of $\mathrm{PdCl}_{2}\left(\mathrm{PPh}_{3}\right)_{2}$ was successful in the synthesis of chalcogenorhodamine dyes [29], the usage of that catalyst gave just low yields when applied in the synthesis of the silicon analogues (Scheme 2) [22]. Although $\mathrm{Pd}\left(\mathrm{PPh}_{3}\right)_{4}$ was not found to be an effective catalyst for the synthesis of rhodamine and rosamine dyes as well as for their selenium or tellurium analogous [29], the usage of that $\operatorname{Pd}(0)$ catalyst showed yields comparable with those obtained with $\mathrm{PdCl}_{2}\left(\mathrm{PPh}_{3}\right)_{2}$ (Table 1, entry 4). The exchange of sodium carbonate with cesium carbonate resulted in no reaction at all (Table 1, entry 5). Whereby usage of potassium phenyltrifluoroborate (19) resulted in a yield comparable to boroxine $\mathbf{1 8 b}$ (Table 1, entry 6), usage of pinacol ester $\mathbf{2 0}$ showed no reaction in the cross-coupling reaction (Table 1, entry 7). Although described optimizations of the reaction conditions could lead to the silicon rhodamine $\mathbf{2 2}$ in moderate yields, an inseparable impurity of the cationic fluorophore was detected. After identifying this impurity as the tetraphenylphosphonium cation, we exchanged the triphenylphosphine ligand of the catalyst with dppf (1,1'-bis(diphenylphosphino)ferrocene). Remarkably, not only the yield was increased with $\mathrm{PdCl}_{2}$ (dppf) from $49 \%$ to $67 \%$, even the dye $\mathbf{2 2}$ was obtained with high purity after column chromatography without the necessity of further HPLC purification (Table 1, entry 8).

\section{Exploration of substrate scope}

Next we explored the substrate scope of the Suzuki-Miyaura coupling by screening commercially available boronic acids (Scheme 4, Table 2). Hereby, $\mathrm{PdCl}_{2}$ (dppf) was also tested in order to suppress the formation of the inseparable phosphonium cation species. At first, we investigated the use of 3-boronobenzoic acid (23a) that should lead to a rhodamine suitable for coupling to a tumor vector, but boroxine $\mathbf{2 3 b}$ was converted to 23c with $\mathrm{PdCl}_{2}\left(\mathrm{PPh}_{3}\right)_{2}$ in poor yields (Scheme 4 and Table 2, entry 1). However, $\mathrm{PdCl}_{2}$ (dppf) performed better and led to the acid-substituted silicon rhodamine $23 \mathbf{c}$ in a moderate yield of $31 \%$ ( $56 \%$ brsm) (Table 2 , entry 2$)$. The moderate yield might be explained with the destruction of the triflate by the acid moiety of $\mathbf{2 3 c}$. In order to prevent the destruction of the initially formed triflate 21, 4-boronobenzaldehyde (24a)

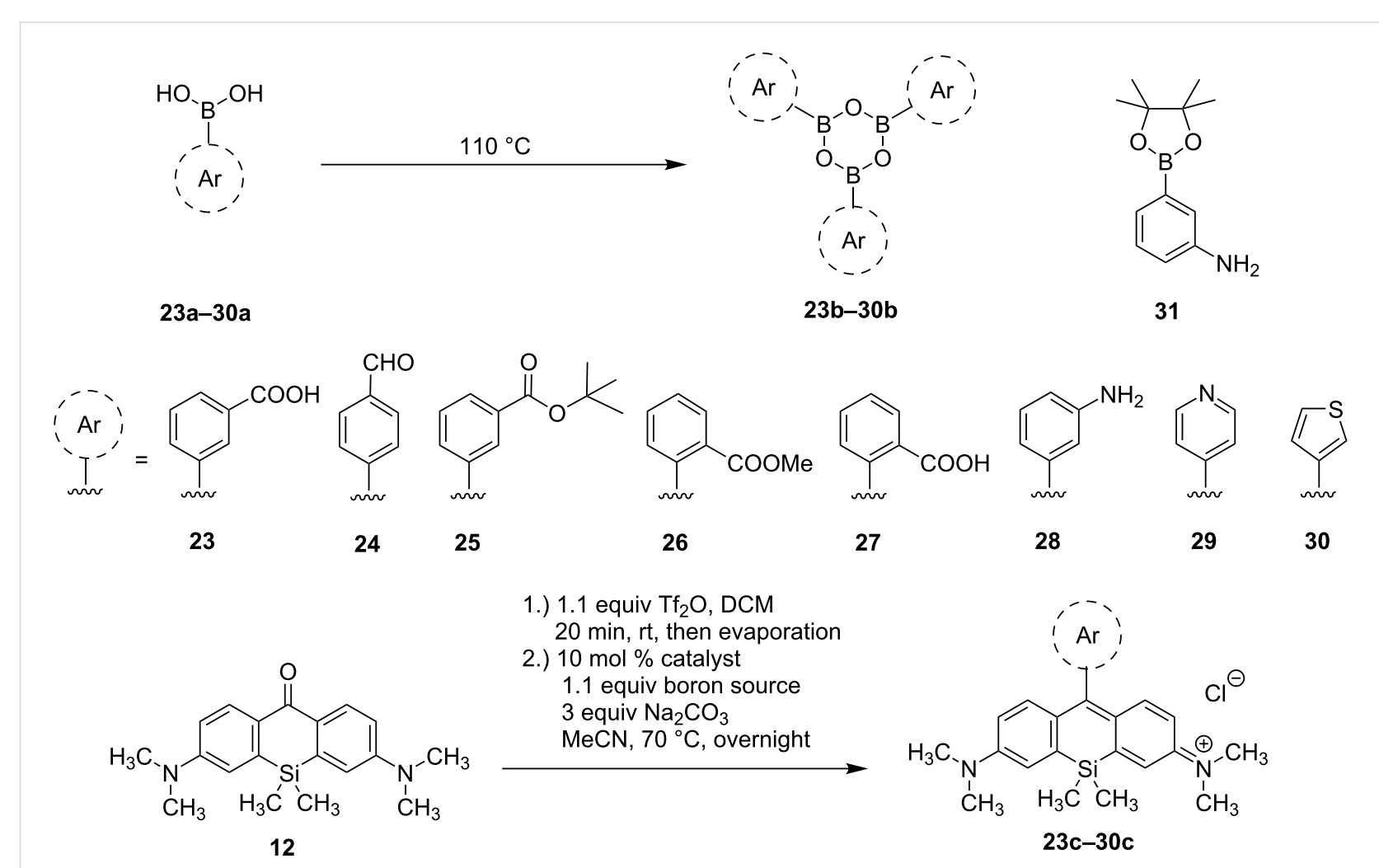


Table 2: Coupling reactions of silicon xanthone 12 with different boron species (23b-30b, 31).

\begin{tabular}{|c|c|c|c|}
\hline Entry & Boron source & Catalyst & Yield \\
\hline 1 & $23 b$ & $\mathrm{PdCl}_{2}\left(\mathrm{PPh}_{3}\right)_{2}$ & $\begin{array}{c}5 \% \mathrm{a}, \\
46 \% \mathrm{a}, \mathrm{b} \\
(\mathbf{2 3 c})\end{array}$ \\
\hline 2 & $23 b$ & $\mathrm{PdCl}_{2}(\mathrm{dppf})$ & $\begin{array}{l}31 \% \\
56 \% \text { b } \\
(23 c)\end{array}$ \\
\hline 3 & $24 b$ & $\mathrm{PdCl}_{2}\left(\mathrm{PPh}_{3}\right)_{2}$ & $\begin{array}{c}\text { traces } \\
(24 \mathrm{c})\end{array}$ \\
\hline 4 & $25 b$ & $\mathrm{PdCl}_{2}\left(\mathrm{PPh}_{3}\right)_{2}$ & $\begin{array}{c}43 \%^{\mathrm{a}}, \\
62 \%{ }^{\mathrm{a}, \mathrm{b}} \\
(\mathbf{2 5 c})\end{array}$ \\
\hline 5 & $25 b$ & $\mathrm{PdCl}_{2}(\mathrm{dppf})$ & $\begin{array}{l}53 \% \\
66 \% \text { b } \\
(25 \mathrm{c})\end{array}$ \\
\hline 6 & $26 b$ & $\mathrm{PdCl}_{2}\left(\mathrm{PPh}_{3}\right)_{2}$ & n.r. \\
\hline 7 & $27 b$ & $\mathrm{PdCl}_{2}\left(\mathrm{PPh}_{3}\right)_{2}$ & n.r. \\
\hline 8 & $28 b$ & $\mathrm{PdCl}_{2}\left(\mathrm{PPh}_{3}\right)_{2}$ & n.r. \\
\hline 9 & 31 & $\mathrm{PdCl}_{2}\left(\mathrm{PPh}_{3}\right)_{2}$ & n.r. \\
\hline 10 & $29 b$ & $\mathrm{PdCl}_{2}\left(\mathrm{PPh}_{3}\right)_{2}$ & n.r. \\
\hline 11 & $30 \mathrm{~b}$ & $\mathrm{PdCl}_{2}\left(\mathrm{PPh}_{3}\right)_{2}$ & $\begin{array}{c}37 \%^{a}, \\
56 \% \text {, b } \\
(30 \mathbf{c})\end{array}$ \\
\hline 12 & $30 \mathrm{~b}$ & $\mathrm{PdCl}_{2}(\mathrm{dppf})$ & $\begin{array}{c}91 \% \\
(30 \mathrm{c})\end{array}$ \\
\hline
\end{tabular}

${ }^{a}$ Corrected yield, contamination with $\left[\mathrm{PPh}_{3} \mathrm{Ar}\right]^{+}$. bBased on recovered starting material (brsm) 12.

was intended as a coupling substrate but yielded silicon rhodamine $\mathbf{2 4 c}$ only in traces (Table 2, entry 3 ). Usage of the tert-butyl-protected boronobenzoic acid 25a, or its boroxine counterpart $\mathbf{2 5 b}$, respectively, gave fluorophore $\mathbf{2 5 c}$ suitable for later coupling reactions in reasonable yields of $43 \%$ and $53 \%$, depending on the catalyst used (Table 2, entries 4 and 5). Again, the reaction catalyzed by $\mathrm{PdCl}_{2}(\mathrm{dppf})$ resulted in an enhanced yield compared to catalysis with $\mathrm{PdCl}_{2}\left(\mathrm{PPh}_{3}\right)_{2}$. Next we aimed at the synthesis of a silicon rhodamine bearing an acid function in 2'-position. With a less bulky methyl ester in the 2'-position of the phenylboroxine, the transmetalation and the new bond formation through reductive elimination should be less hindered, but remarkably, no reaction was observed either with the methyl ester $\mathbf{2 6 b}$ or the free acid $\mathbf{2 7} \mathbf{b}$ (Table 2, entries 6 and 7). Next we explored if amino-substituted silicon rhodamine 28c is accessible via Pd-catalysis. The resulting rhodamine 28c could be a possible substrate for the conversion into an azide and follow-up click reactions with alkyne-substituted tumor vectors. While heating of amine 28a to the corresponding boroxine $\mathbf{2 8 b}$ lead to formation of a brown solid (presumably due to degradation), the reaction of triflate $\mathbf{2 1}$ with the pinacol ester $\mathbf{3 1}$ showed no product formation at all (Table 2, entries 8 and 9). Since we were able to investigate the functional group tolerance of the coupling reaction, we shifted our focus towards heterocyclic boronic acids as substrates. Since 4'-pyridinyl- [27,30] and 3'-thienyl- [27,31-33] substituted silicon rhodamines are already known, we investigated the synthesis of these dyes by Suzuki-Miyaura cross coupling. Firstly, pyridinylboronic acid 29a was used as a substrate after heating at $110{ }^{\circ} \mathrm{C}$, but no conversion was observed presumably due to the formation of an internal salt (protonated pyridine ring and deprotonated boronic acid) and ensuing difficult formation of boroxine 29b (Table 2, entry 10). Switching to the neutral heterocyclic boronic acid 30a, the corresponding thienyl-substituted silicon rhodamine 30c could be obtained in 37\% $(56 \%$ brsm) yield with the $\mathrm{PdCl}_{2}\left(\mathrm{PPh}_{3}\right)_{2}$ catalyst. Remarkably, the yield could be clearly enhanced by catalysis with $\mathrm{PdCl}_{2}$ (dppf) and the thienyl-substituted fluorophore 30c could subsequently be synthesized in $91 \%$ yield.

Table 3 compares the reaction outcome of the silicon rhodamine synthesis via Suzuki coupling with other employed methods: synthesis of the phenyl-substituted silicon rhodamine 22 by Suzuki cross coupling affords the product in a similar yield compared to the addition of phenyllithium to xanthone $\mathbf{1 2}$ or the attack of the double metallated bis-aniline $4\left(\mathrm{R}^{1}=\mathrm{R}^{2}=\mathrm{Me}\right.$, $\mathrm{M}=\mathrm{Mg}$ ) to the benzoic acid methyl ester [26]. However, the cross coupling of triflate $\mathbf{2 1}$ with boroxine $\mathbf{2 5 b}$ led to the estersubstituted rhodamine $25 \mathrm{c}$ in a reasonable yield of 53\% $(66 \%$

Table 3: Comparison of common methods for silicon rhodamine synthesis

\begin{tabular}{|c|c|c|c|}
\hline Fluorophore $\downarrow$ & $\begin{array}{l}\text { Addition of lithium organyl } \\
\text { to } 12^{\mathrm{a}}\end{array}$ & $\begin{array}{l}\text { Suzuki-Miyaura } \\
\text { cross coupling }\end{array}$ & $\begin{array}{c}\text { Attack of } 4\left(R^{1}=R^{2}=M e\right. \\
M=M g) \text { to } 5\left(R^{3}=H\right)\end{array}$ \\
\hline phenyl-substituted SiR (22) & $72 \%$ & $\begin{array}{l}67 \% \\
73 \% \text { b }\end{array}$ & $72 \%[26]$ \\
\hline $\begin{array}{l}\text { tert-butylbenzoic } \\
\text { acid-substituted SiR (25c) }\end{array}$ & $7 \%$ & $\begin{array}{l}53 \% \\
66 \% \text { b }\end{array}$ & - \\
\hline thienyl-substituted SiR (30c) & $77 \%$ & $91 \%$ & - \\
\hline
\end{tabular}

aConditions: 7 equiv aryl bromide, 14 equiv $t$-BuLi, THF, $-78^{\circ} \mathrm{C}, 30 \mathrm{~min}$, then 1 equiv 12 at $-78{ }^{\circ} \mathrm{C}$ to rt, overnight, then aq $\mathrm{HCl}$, work-up, purification with $\mathrm{DCM} / \mathrm{MeOH}$ 99:1 to 9:1. ${ }^{\mathrm{b}}$ Based on recovered starting material (brsm) 12. 
brsm) while the addition of the lithiated tert-butyl 3-bromobenzoate gave the fluorophore $\mathbf{2 5 c}$ in only $7 \%$ yield. Finally, the cross-coupling reaction of $\mathbf{1 2}$ and $\mathbf{3 0 b}$ to rhodamine $\mathbf{3 0 c}$ clearly outperforms the addition of lithiated 2-bromothiophene to xanthone 12 since 2-bromothiophene might also undergo lithiation in 5-position in competition to the halogen metal exchange (in general multiple halogenated aryls are problematic nucleophiles for these addition reactions).

\section{Conclusion}

Since just three literature examples are known to date in which Suzuki-Miyaura cross-coupling reactions gave access to silicon rhodamines in poor to moderate yields (Scheme 2), we wanted to improve these first valuable experimental results. In general, the amount of re-isolated starting material 12 could be significantly reduced when acetonitrile was exchanged with dichloromethane in the triflation reaction to provide triflate $\mathbf{2 1}$ neat and more reliable. Screening of different boron species and catalysts showed that, like in the syntheses of $\mathrm{O}, \mathrm{S}, \mathrm{Se}$, and Te-rhodamines, boroxines were a suitable source, but also potassium trifluoroborates can be taken into consideration for the reaction design, whereas pinacol esters didn't show any reactivity. While $\mathrm{PdCl}_{2}\left(\mathrm{PPh}_{3}\right)_{2}$ was a sufficient catalyst for the cross coupling, application of $\mathrm{PdCl}_{2}$ (dppf) led to clearly enhanced yields: overall the Suzuki-Miyaura cross-coupling reaction gave access to silicon rhodamines with neutral (hetero)aromatic xanthene substituents (phenyl: $67 \%$, respectively $73 \%$ brsm; thienyl: 91\%) (even though the term 'dihydrosilaanthracene' is correct to name the Si-anthracene moiety, the term 'Si-xanthene' is widely used in the literature (see e.g. [30]); also the term Si-xanthone (for derivatives of $\mathbf{1 2}$ ) is established instead of 9-silaanthracen-10(9H)-one). The conditions tolerated also the use of the unprotected acid functionality of the boroxine $23 \mathrm{~b}$ (23c, 31\%, respectively 56\% brsm), while application of basic boronic acids failed $(\mathbf{2 8}, \mathbf{2 9})$, presumably due to unsuccessful boroxine formation. The main advantage of the cross coupling is the access to acid-functionalized fluorophores like 23c that can be immediately coupled to a molecule of interest (e.g., tumor binding vectors) whereas previously published methodologies need, e.g., an ester, orthoester or oxazoline protecting group for the acid. But also the tert-butyl ester-functionalized boroxine $\mathbf{2 5}$ is suitable for the cross coupling. With the current catalytic system, coupling of 2-substituted boroxines $(\mathbf{2 6}, \mathbf{2 7})$ remains challenging, but optimizing the catalytic system with ligands suitable for coupling of multisubstituted aryls is under current investigation. In conclusion, several silicon rhodamines could be synthesized under the optimized conditions, without the necessity of HPLC purification, in up to $91 \%$ yield whereby the free acids are directly accessible in contrast to the three hitherto described methods.

\section{Supporting Information}

\section{Supporting Information File 1}

Experimental procedures and NMR spectra of all synthesized compounds as well as photochromic characterization data (fluorescence spectra, quantum yield) of thienyl-substituted silicon rhodamine 30c.

[https://www.beilstein-journals.org/bjoc/content/ supplementary/1860-5397-15-250-S1.pdf]

\section{Acknowledgements}

We are very grateful to the Wilhelm Sander Stiftung for a grant on bi-modal tumor tracers (2018.024.1). We thank Yvonne Remde for synthetic support. We are thankful to Jessica Matthias (group of Stefan Hell, MPI for Medical Research Heidelberg) for measurement of the UV-vis spectrum of 30c.

\section{ORCID ${ }^{\circledR}$ iDs}

Thines Kanagasundaram - https://orcid.org/0000-0001-8265-8591 Antje Timmermann - https://orcid.org/0000-0002-9557-9320 Carsten S. Kramer - https://orcid.org/0000-0001-9932-423X Klaus Kopka - https://orcid.org/0000-0003-4846-1271

\section{References}

1. Thompson, A. D.; Omar, M. H.; Rivera-Molina, F.; Xi, Z.; Koleske, A. J.; Toomre, D. K.; Schepartz, A. Angew. Chem., Int. Ed. 2017, 56, 10408-10412. doi:10.1002/anie.201704783

2. Butkevich, A. N.; Ta, H.; Ratz, M.; Stoldt, S.; Jakobs, S.; Belov, V. N.; Hell, S. W. ACS Chem. Biol. 2018, 13, 475-480. doi:10.1021/acschembio.7b00616

3. Butkevich, A. N.; Mitronova, G. Y.; Sidenstein, S. C.; Klocke, J. L.; Kamin, D.; Meineke, D. N. H.; D'Este, E.; Kraemer, P.-T.; Danzl, J. G.; Belov, V. N.; Hell, S. W. Angew. Chem., Int. Ed. 2016, 55, 3290-3294. doi:10.1002/anie.201511018

4. Kozma, E.; Estrada Girona, G.; Paci, G.; Lemke, E. A.; Kele, P. Chem. Commun. 2017, 53, 6696-6699. doi:10.1039/c7cc02212c

5. Grimm, J. B.; Klein, T.; Kopek, B. G.; Shtengel, G.; Hess, H. F.; Sauer, M.; Lavis, L. D. Angew. Chem., Int. Ed. 2016, 55, 1723-1727. doi:10.1002/anie.201509649

6. Lukinavičius, G.; Reymond, L.; Umezawa, K.; Sallin, O.; D’Este, E.; Göttfert, F.; Ta, H.; Hell, S. W.; Urano, Y.; Johnsson, K. J. Am. Chem. Soc. 2016, 138, 9365-9368. doi:10.1021/jacs.6b04782

7. Takakura, H.; Zhang, Y.; Erdmann, R. S.; Thompson, A. D.; Lin, Y.; McNellis, B.; Rivera-Molina, F.; Uno, S.-n.; Kamiya, M.; Urano, Y.; Rothman, J. E.; Bewersdorf, J.; Schepartz, A.; Toomre, D. Nat. Biotechnol. 2017, 35, 773-780. doi:10.1038/nbt.3876

8. Lukinavičius, G.; Umezawa, K.; Olivier, N.; Honigmann, A.; Yang, G.; Plass, T.; Mueller, V.; Reymond, L.; Corrêa, I. R., Jr.; Luo, Z.-G.; Schultz, C.; Lemke, E. A.; Heppenstall, P.; Eggeling, C.; Manley, S.; Johnsson, K. Nat. Chem. 2013, 5, 132-139. doi:10.1038/nchem.1546

9. Shieh, P.; Siegrist, M. S.; Cullen, A. J.; Bertozzi, C. R. Proc. Natl. Acad. Sci. U. S. A. 2014, 111, 5456-5461. doi:10.1073/pnas.1322727111 
10. Iwatate, R. J.; Kamiya, M.; Umezawa, K.; Kashima, H.; Nakadate, M.; Kojima, R.; Urano, Y. Bioconjugate Chem. 2018, 29, 241-244. doi:10.1021/acs.bioconjchem.7b00776

11. Kim, E.; Yang, K. S.; Kohler, R. H.; Dubach, J. M.; Mikula, H.; Weissleder, R. Bioconjugate Chem. 2015, 26, 1513-1518. doi:10.1021/acs.bioconjchem.5b00152

12. Hanaoka, K.; Kagami, Y.; Piao, W.; Myochin, T.; Numasawa, K.; Kuriki, Y.; Ikeno, T.; Ueno, T.; Komatsu, T.; Terai, T.; Nagano, T.; Urano, Y. Chem. Commun. 2018, 54, 6939-6942. doi:10.1039/c8cc02451k

13. Du, M.; Huo, B.; Liu, J.; Li, M.; Fang, L.; Yang, Y. Anal. Chim. Acta 2018, 1030, 172-182. doi:10.1016/j.aca.2018.05.013

14. Koide, Y.; Urano, Y.; Hanaoka, K.; Terai, T.; Nagano, T. ACS Chem. Biol. 2011, 6, 600-608. doi:10.1021/cb1002416

15. Wang, T.; Zhao, Q.-J.; Hu, H.-G.; Yu, S.-C.; Liu, X.; Liu, L.; Wu, Q.-Y. Chem. Commun. 2012, 48, 8781. doi:10.1039/c2cc34159j

16. Wang, B.; Cui, X.; Zhang, Z.; Chai, X.; Ding, H.; Wu, Q.; Guo, Z.; Wang, T. Org. Biomol. Chem. 2016, 14, 6720-6728. doi:10.1039/c6ob00894a

17. Egawa, T.; Hanaoka, K.; Koide, Y.; Ujita, S.; Takahashi, N.; Ikegaya, Y.; Matsuki, N.; Terai, T.; Ueno, T.; Komatsu, T.; Nagano, T. J. Am. Chem. Soc. 2011, 133, 14157-14159. doi:10.1021/ja205809h

18. Huang, Y.-L.; Walker, A. S.; Miller, E. W. J. Am. Chem. Soc. 2015, 137, 10767-10776. doi:10.1021/jacs.5b06644

19. Zhang, H.; Liu, J.; Liu, C.; Yu, P.; Sun, M.; Yan, X.; Guo, J.-P.; Guo, W. Biomaterials 2017, 133, 60-69. doi:10.1016/j.biomaterials.2017.04.023

20. Huo, Y.; Miao, J.; Han, L.; Li, Y.; Li, Z.; Shi, Y.; Guo, W. Chem. Sci. 2017, 8, 6857-6864. doi:10.1039/c7sc02608k

21. Koide, Y.; Urano, Y.; Hanaoka, K.; Terai, T.; Nagano, T. J. Am. Chem. Soc. 2011, 133, 5680-5682. doi:10.1021/ja111470n

22. Umezawa, K.; Yoshida, M.; Kamiya, M.; Yamasoba, T.; Urano, Y. Nat. Chem. 2017, 9, 279-286. doi:10.1038/nchem.2648

23. McCann, T. E.; Kosaka, N.; Koide, Y.; Mitsunaga, M.; Choyke, P. L.; Nagano, T.; Urano, Y.; Kobayashi, H. Bioconjugate Chem. 2011, 22 , 2531-2538. doi:10.1021/bc2003617

24. Koide, Y.; Urano, Y.; Hanaoka, K.; Piao, W.; Kusakabe, M.; Saito, N.; Terai, T.; Okabe, T.; Nagano, T. J. Am. Chem. Soc. 2012, 134, 5029-5031. doi:10.1021/ja210375e

25. Wang, B.; Chai, X.; Zhu, W.; Wang, T.; Wu, Q. Chem. Commun. 2014, 50, 14374-14377. doi:10.1039/c4cc06178k

26. Fischer, C.; Sparr, C. Angew. Chem., Int. Ed. 2018, 57, 2436-2440. doi:10.1002/anie.201711296

27. Grimm, J. B.; Brown, T. A.; Tkachuk, A. N.; Lavis, L. D. ACS Cent. Sci. 2017, 3, 975-985. doi:10.1021/acscentsci.7b00247

28. Urano, Y.; Kamiya, M.; Umezawa, K.; Yoshida, M. Glutathione-detecting fluorescent probe. U.S. Pat. Appl. US2017/0045525 A1, Feb 16, 2017.

29. Calitree, B. D.; Detty, M. R. Synlett 2010, 89-92. doi:10.1055/s-0029-1218535

30. Zhang, H.; Li, K.; Li, L.-L.; Yu, K.-K.; Liu, X.-Y.; Li, M.-Y.; Wang, N.; Liu, Y.-H.; Yu, X.-Q. Chin. Chem. Lett. 2019, 30, 1063-1066. doi:10.1016/j.cclet.2019.03.017

31. Groves, K.; Bruff, R. Substituted silaxanthenium red to near-infrared fluorochromes for in vitro and in vivo imaging and detection. WO Pat. Appl. WO2014/144793 A1, Sept 18, 2014.

32. Gamsey, S.; Bernat, V.; Kutyavin, A.; Clary, J. W.; Pradhan, S. Near-IR Glucose Sensors. U. S..Pat. Appl. US20180179233 A1, June 28, 2018.

33. Urano, Y.; Kamiya, M.; Tachibana, R. Preparation of spiro compounds as red fluorescent probes for use in detection of peptdase activity. WO Pat. Appl. WO 2018151260 A1, Aug 23, 2018.

\section{License and Terms}

This is an Open Access article under the terms of the Creative Commons Attribution License (http://creativecommons.org/licenses/by/4.0). Please note that the reuse, redistribution and reproduction in particular requires that the authors and source are credited.

The license is subject to the Beilstein Journal of Organic Chemistry terms and conditions: (https://www.beilstein-journals.org/bjoc)

The definitive version of this article is the electronic one which can be found at: doi:10.3762/bjoc. 15.250 